\title{
KESESUAIAN PEMIKIRAN DAN AMALAN MAZHAB SELAIN SYAFI I DALAM MASYARAKAT ISLAM DI MALAYSIA: SATU ANALISIS AWAL
}

\author{
Saadan Man* \\ Abdul Karim Ali** \\ Luqman Hj Abdullah ${ }^{* * *}$ \\ Rushdi Ramli ${ }^{* * * *}$ \\ Inarah Ahmad Farid ${ }^{* * * * *}$
}

\begin{abstract}
The influence of Syafi' $i$ madhdhab is deeply entrenched in Malay Muslim society since the advent of Islam to the Malay world. The Malay Muslims' attachment to the madhdhab is regarded as a sacrosanct tradition and it has never been contested until the emergence of Islamic reform movement in about a century ago. Among their major themes of reform is an idea called "borderless fiqh" which is viewed as an attempt to break the domination of Syafi 'i madhhab in Malay world. This attempt has resulted in controversy among scholars as well as among the Muslim community who view it as a kind of heresy and does not suit the common norms of Malaysian Muslim society. This paper aims at analysing the claim that the teachings of Islamic reform, particularly
\end{abstract}

\footnotetext{
* Pensyarah Kanan, Jabatan Fiqh \& Usul, Akademi Pengajian Islam, Universiti Malaya, Kuala Lumpur.

** Prof. Madya, Jabatan Fiqh \& Usul, Akademi Pengajian Islam, Universiti Malaya, Kuala Lumpur.

*** Pensyarah Kanan, Jabatan Fiqh \& Usul, Akademi Pengajian Islam, Universiti Malaya, Kuala Lumpur.

**** Pensyarah Kanan, Jabatan Fiqh \& Usul, Akademi Pengajian Islam, Universiti Malaya, Kuala Lumpur.

${ }^{* * * * *}$ Pembantu Penyelidik, Jabatan Fiqh \& Usul, Akademi Pengajian Islam, Universiti Malaya, Kuala Lumpur.
} 
in this issue, are not suitable for Malays Muslim society. It also identifies the reality and issues revolving holding to a sole madhhab among the community. This paper is based on research which undertook several methods, mainly observations and interviews with scholars and those who hold religious authority. The research finds that, to some extent, the openess to other madhhabs is considered by many as one of a main factor that contributes to division among muslim community in Malaysia and thus threathens their harmonic religious life. However, reform is still necessary in order to induce religious awareness among the community, on a condition that it should be undertook by proper manners and appropriate approaches that suit to the reality of Malaysian Muslim society.

Keywords: Madhhab, Syafi'i Madhhab, Islamic Reform, Ikhtilaf, Conflict, Malay Muslim Society.

\section{PENDAHULUAN}

Kewujudan mazhab atau aliran fiqh merupakan satu fenomena tradisi yang tidak dapat dielakkan dalam realiti umat Islam hari ini. Ia adalah sebagai satu manifestasi sejarah kepada hakikat wujudnya perbezaan pendapat dan tafsiran terhadap nas-nas syarak dan pengolahan penyelesaian kepada isu-isu yang berbangkit. Antara sudut positif kewujudan pelbagai mazhab fiqh ini ialah ia menjadi satu mekanisme penting dalam pengusulan cadangan penyelesaian terhadap beberapa isu kompleks yang dihadapi oleh masyarakat.

Perbezaan pendapat atau ikhtilāf dalam kalangan manusia merupakan satu perkara yang lumrah dalam realiti sejarah kehidupan mereka. Demikian juga dalam Islam, hal ini menjadi satu aspek yang tidak mungkin dapat dipisahkan dari sifat tabie 
manusia. Bahkan sebenarnya perbezaan pendapat itu menjadikan Islam itu agama yang dinamis dan fleksibel. ${ }^{1}$

Perdebatan dan perbezaan pendapat dalam Islam melibatkan pelbagai persoalan berhubung agama. Menurut Muhammad Abū Zahrah, perbezaan pendapat ini kebanyakannya hanya berlaku dalam masalah-masalah fur $\bar{u}^{6}$ sahaja. ${ }^{2}$ Walaupun demikian, sejarah menyaksikan perbezaan pendapat seperti itu seringkali membawa kepada sesuatu yang lebih serius seperti lahirnya fenomena takfir antara sesama Muslim. Malah pernah berlaku pertumpahan darah di antara kumpulan-kumpulan tertentu yang bertelagah dalam soalsoal yang remeh sehingga membawa kepada penyakit perpecahan umat yang kronik. Ini membuktikan bahawa perbezaan-perbezaan pendapat mengenai perkara-perkara furu ' ini mempunyai nilainilai yang sensitif di sisi sesetengah pihak jika persepsi terhadapnya tidak diuruskan dengan betul.

\section{POLEMIK MASYARAKAT ISLAM DALAM REALITI DI MALAYSIA}

Menelusuri sejarah perkembangan mazhab di Malaysia, masyarakat Islam di sini secara tradisinya telah lama menerima dan mengamalkan Islam berdasarkan kepada pendekatan Ahl alSunnah wa al-Jama'ah dari sudut aqidah dan fiqhnya. Fahaman Asyā 'irah dan Màturidiyyah menjadi pegangan rasmi dalam aspek akidah, manakala mazhab Syafi'i adalah pegangan dalam hukum dan amalan agamanya. Pengaruh berkenaan sudah membentuk sebahagian utama daripada tradisi kehidupan beragama, malah di kalangan masyarakat awam, mazhab Syafi'i telah membentuk sebahagian daripada makna agama pada persepsi dan kefahaman

'Abd al-Karīm Zaydān (t.t.), al-Khilāf fì al-Syarī'ah al-Islāmiyyah. Beirut: Mu'assasah al-Risālah, hh. 14-15; Ṭahā Jābir al-'Alwānī (1987), Adab al-Ikhtilāffí al-Islām. USA: IIIT, Virginia, h.13; Yūsuf al-Qaraḍāwī (1995), al-Ṣahwat al-Islāmiyyah Bayn al-Ikhtiläf alMasyrū' wa al-Ikhtilāf al-Madhmūm. Kaherah: Dār al-Syurūq, h. 44; Muḥammad 'Abd al-Laṭîf Mạ̣mūd (2000), al-Ikhtilāfāt alFiqhiyyah ladā al-Ittijāhāt al-Islāmiyyah al-Mu'āṣirah. Kaherah: Dār al-Wafā', h. 20.

2 Muhammad Abū Zahrah (t.t), Tārīkh al-Madhāhib al-Islāmiyyah. Kaherah: Dār-al-Fikr, h. 11. 
mereka. Pegangan ini tidak pernah diganggu gugat sehinggalah pada awal kurun ke-20 dengan kedatangan aliran iṣlāh dan tajdìd yang mempromosikan pemikiran Salafiyyah dalam akidah dan fiqh tanpa sempadan mazhab dalam hukum dan amalan. Kemunculan aliran ini telah mencetuskan kontroversi yang berpanjangan hingga ke hari ini sama ada di peringkat masyarakat awam atau ulama, terutamanya apabila menyentuh tentang pemikiran dan amalanamalan baru yang dilihat berbeza, bercanggah dan bertentangan dengan amalan tradisi mereka.

Satu aspek yang signifikan dalam perkara ini ialah aliran baru ini sering disebut sebagai tidak sesuai dengan masyarakat setempat. Ajaran, pemikiran dan amalan-amalan aliran ini dilihat bercanggah dengan norma-norma masyarakat yang telah cukup selesa dengan pemikiran dan amalan tradisi. Sebarang usaha reformasi agama yang cuba dibawa oleh aliran berkenaan sukar diterima, malah dianggap bertentangan dengan aspirasi dan budaya masyarakat tempatan. Pandangan-pandangan, syor dan kritikan dari aliran ini dalam usaha mereka untuk mengislahkan ummah sering mendapat reaksi negatif dari kalangan ulamak tradisi yang memegang autoriti agama.

Sejak kemunculan aliran iṣlạh dan tajdìd, maka lahirlah dua kelompok yang saling bertentangan, di mana kelompok pertama terdiri daripada ulama-ulama tradisional yang berpegang kepada tradisi konservatif atau mempertahankan yang lama. ${ }^{3}$ Mereka melihat sejarah atau masa lampau sebagai sumber inspirasi atau sesuatu yang harus dipertahankan. Di dalam banyak perkara, mereka lebih suka mengekalkan status quo sesuatu amalan yang telah lama bertapak dalam masyarakat.

Justeru, kumpulan tradisional atau lebih dikenali sebagai Kaum Tua ini dilihat seringkali bersikap negatif terhadap pembaharuan dan perubahan. Golongan ini seringkali menganggap bahawa kemunduran umat Islam adalah kerana mereka menjauhkan diri daripada ajaran-ajaran generasi yang lalu, serta memutuskan

3 Abdul Rahman Haji Abdullah (1998), Pemikiran Islam di Malaysia: Sejarah dan Aliran. Kuala Lumpur: Dewan Bahasa dan Pustaka, h. 5. Lihat juga Karl Mannheim (1966), "Conservative Tought", dalam K.Mannheim, Essays on Sociology and Social Psychology. London : Routledge \& Kegan Paul, hh. 95 \& 96. 
hubungan tradisi mereka untuk mengikuti arus perubahan iaitu godaan syaitan dari Barat. ${ }^{4}$ Mereka kadangkala dilihat oleh sebilangan sarjana sebagai lebih "selesa untuk mengurung Islam dalam satu benteng tanpa jendela dan pintu keluar, tanpa ruangan terbuka ke arah langit, serta mempertahankan seluruh tradisi yang telah diwarisi oleh nenek moyang tanpa membezakan ajaran Islam yang tulen atau campuran dari pelbagai pengaruh yang lain". ${ }^{5}$

Ditinjau dari satu sudut, memang benar aliran tradisionalisme cuba mempertahankan tradisi yang asal dan tulen. Bagaimanapun keaslian dan ketulenan dalam konteks ini lebih merujuk kepada ajaran-ajaran para ulama madhabiyyah atau yang bertaklid kepada imam-imam mazhab yang empat. Dari sudut sejarah, budaya bertaklid dan kebekuan ijtihad ini khususnya di alam Melayu kelihatan pada dasarnya berlaku dalam bidang fiqh. Kebanyakan rujukannya bukanlah kepada karya asal atau ajaran-ajaran Imam Mujtahid, tetapi kepada karya-karya para ulama madhabiyyah. Karya-karya ini muncul di dalam bentuk syarah, hāsyiyah atau hâmisy yang mana kandungannya kadang-kadang lebih sukar untuk difahami dari kitab matan atau induk. ${ }^{6}$

Ini adalah kesimpulan gambaran secara umum kumpulan tradisional ataupun Kaum Tua sebagaimana yang rumuskan oleh para sarjana. Nik Abdul Aziz bin Nik Hassan merumuskan gambaran kumpulan tradisionalis atau Kaum Tua ini sebagai:

"Ulama-ulama yang enggan menerima pemikiran yang baru yang bercanggah dengan aliran-aliran pemikiran Islam yang sudah pun berakar umbi di kalangan masyarakat Melayu tempatan.. "7

Manakala kelompok yang kedua pula adalah terdiri daripada golongan ulama yang mendokong idealisme pembaharuan yang dikenali sebagai reformis atau Kaum Muda. Ulama ini dikatakan

Abdul Rahman Haji Abdullah, op.cit, h. 6.

Roger Garaudy (1982), Janji-janji Islam (terj.). Jakarta: Bulan Bintang, hh. 223-224.

Abdul Rahman Haji Abdullah, op.cit, h. 7.

Nik Abdul Aziz bin Nik Hassan (1983), "Islam dan Masyarakat Kota Bharu Sekitar Tahun 1900-1940", dalam Nik Abdul Aziz bin Nik Hassan, Islam di Kelantan. Kuala Lumpur: Persatuan Sejarah Malaysia, h. 19. 
cuba membawa suatu pendekatan yang baru dalam ajaran agama. Dalam perjuangan mereka, Kaum Muda ini menyeru anggota masyarakat supaya kembali kepada ajaran asli Islam iaitu alQuran dan al-Sunnah serta mengamalkan ijtihad. ${ }^{8}$ Ulama Kaum Muda sangat menekankan kepada usaha iṣlāh atau tajdìd. Ișlāh di sini bermakna memperbaiki atau membersihkan Islam daripada pemalsuan dan penyelewengan. Sedangkan tajdìd pula bermakna memperbaharui dan menyegarkan semula kefahaman dan komitmen terhadap ajaran-ajaran agama sesuai dengan tuntutan zaman. ${ }^{9}$ Amalan-amalan yang disifatkan sebagai bid 'ah atau khurafat atau dalam erti kata lain amalan-amalan yang diadakan oleh orang-orang terkemudian yang tidak pun diamalkan oleh Rasulullah SAW.

Dalam sejarah Islam, ramai reformis atau muṣlih yang menjadi korban kepada langkah atau gerakan reformasi yang mereka anjurkan sendiri. Sebab yang paling utama ialah tabiat semulajadi manusia yang sukar untuk berubah. Di samping itu, perubahan juga biasanya mengancam kedudukan pihak-pihak tertentu, dan kerana itu ia ditentang sama ada dipercayai tidak benar atau sebaliknya.

Antara faktor lain yang memberi kesan negatif lain dari manamana gerakan reformasi ialah sikap keterlaluan para reformis dalam memberi perhatian kepada sesuatu aspek perjuangan sehingga terlajak dari batas-batas yang sepatutnya. Akibatnya, reformasi itu sendiri membawa masalah baru di samping tidak mampu menyelesaikan masalah lama. Yūsuf al-Qaraḍāwī dalam karyanya al-Ijtihād al-Mu' $\bar{a}$ șir ${ }^{10}$ ada menyebut beberapa kesalahan umum dalam melakukan ijtihad kontemporari sebagai salah satu dari agenda iṣlāh. Antara kesalahan-kesalahan tersebut ialah kurang memahami realiti dan keterlaluan dalam memberi perhatian kepada sesuatu persoalan. Kaedah terbaik bukanlah menyogok masyarakat dengan fatwa-fatwa baru yang kontroversial, tetapi sebaliknya mendidik masyarakat secara sederhana ke arah perubahan paradigma tentang konsep hukum dan pemikiran fiqh itu sendiri. Tegasnya, gerakan iṣlāh perlu bermula dengan

\footnotetext{
8 Ibid., h. 15.

9 Adul Rahman Abdullah, op.cit, h. 13.

10 Yūsuf al-Qaraḍāwī (1994), al-Ijtihād al-Mu'āṣir Bayn al-Indibāt wa al-Infirāt. Kaherah: Dār al-Tawzī', hh. 30-31.
} 
menyedarkan masyarakat tentang falsafah hukum yang betul dan bukan dengan mengejutkan mereka dengan kesimpulankesimpulan hukum yang kontroversial. ${ }^{11}$

\section{KEDUDUKAN MAZHAB SELAIN SYAFI'I DI MALAYSIA}

Umat Islam di Asia Tenggara ini khususnya masyarakat Melayu dikenali sebagai penganut Mazhab Syafi'i yang setia. Dipercayai bahawa mereka telah beramal dengan hukum-hukum fiqh dari Mazhab Syafi'i sejak kedatangan Islam ke Alam Melayu ini lagi, lantaran pendakwah-pendakwah Islam yang bertanggungjawab menyebarkan Islam di rantau ini adalah dari kalangan mereka yang bermazhab Syafi'i. Pengaruh Mazhab Syafi'i menjadi amat dominan kerana tiada persaingan darimazhab lain. Kedudukan serta perngaruh mazhab ini dalam masyarakat Melayu diperkukuhkan melalui sistem perundangan dan pendidikan. Dengan itu, mazhab Syafi'i menjadi mazhab rasmi bagi masyarakat Melayu dan tidak keterlaluan jika dikatakan bahawa orang-orang Melayu adalah penganut mazhab Syafi'i yang fanatik. ${ }^{12}$

Pengaruh mazhab Syafi'i yang sudah sebati dalam jiwa masyarakat Melayu menyebabkan wujud satu perasaan tidak selesa apabila ada unsur-unsur pengaruh mazhab lain yang cuba dibawa masuk ke dalam masyarakat oleh gerakan ișlăh atau reformisme. Gerakan reformisme yang memperjuangkan kebebasan bermazhab telah dianggap sebagai menyeleweng yang menggugat kestabilan dan kesatuan umat Melayu. Sebaliknya golongan reformis menganggap bahawa keterikatan golongan tradisonalis terhadap mazhab Syafi'i ini sebagai satu sikap taqsub yang ekstrem dan dilarang oleh agama serta menyebabkan kesukaran dan membebankan seseorang individu muslim. Mengikat diri kepada sesuatu mazhab tertentu pada pandangan reformis adalah satu

\footnotetext{
11 Ibid.

12 Abdullah Ishak (1992), Islam di Nusantara, cet. 2. Kuala Lumpur: BAHEIS, JPM, h. 192.
} 
perbuatan yang tidak pernah dianjurkan oleh agama malah boleh menyebabkan perpecahan ummah. ${ }^{13}$

Golongan reformis dalam usaha mereka membebaskan keterikatan masyarakat kepada mazhab Syafi 'i telah menganjurkan idea fiqh tanpa sempadan, iaitu satu pendekatan terbuka mempelajari hukum fiqh berdasarkan kepada dalil Quran dan Sunnah serta pendapat-pendapat mazhab yang ditarjīhkan, yang juga dikenali sebagai Figh Sunnah, Fiqh al-Kitab wa Sunnah atau Fiqh al-Muqaran. Pembelajaran fiqh seperti ini dianggap lebih baik dari pengajian dari kitab-kitab kuning dalam satu mazhab kerana ia meluaskan ufuk pemikiran dan lebih sesuai dalam konteks semasa.

Polemik yang berpanjangan antara reformis dan tradisionalis berhubung isu ini, walaupun banyak mencetuskan impak yang negatif, tetapi sebenarnya juga telah memberikan kesan yang positif dalam konteks pemikiran hukum semasa. Kalangan tradisionalis kelihatan telah merubah sikap mereka dalam menerima pandangan-pandangan mazhab lain. Kaedah talfiq, iaitu proses menerima dan beramal dengan hukum-hukum dari mazhab lain dapat diterima dengan baik oleh masyarakat, malah kalangan tradisionalis sendiri berpendapat bahawa beramal dengan talfiq adalah lebih baik dari bertaklid kepada satu mazhab khusus. ${ }^{14}$ Bagaimanapun, ini tidak bererti bahawa mazhab Syafi'i kehilangan pengaruhnya dalam masyarakat dan pendapat mazhab lain diterima secara berleluasa, sebaliknya ia merupakan satu langkah ke hadapan bagi memastikan keperluan-keperluan dan kepentingan masyarakat dapat dipelihara.

Justeru, kita melihat jika dahulunya mereka tidak selesa dengan ajaran dari mazhab lain, secara berperingkat-peringkat keadaan ini telah berubah, di mana mutakhir ini para sarjana kelihatan cukup terbuka dalam menerima pakai pandangan-pandangan mazhab lain khususnya dalam bidang pengurusan muamalat dan

13 Lihat kupasan ini dalam Saadan Man (2004), "Islamic Reform: The Conflict Between Tradisionalists and Reformists Concerning Matters of Ibadah in Contemporary Malaysia", Tesis $\mathrm{PhD}$, University of Edinburgh, hh. 280-286.

14 Othman Ishak (1985), "Talfiq Dalam Perundangan Islam", dalam ISLAMIKA. Kuala Lumpur: Muzium Negara, h. 98. 
kewangan Islam semasa terutamanya produk-produk perbankan Islam seperti bay'al-wafä', bay'al-'inah dan bay'al-dayn. ${ }^{15}$

Dalam hal-hal ibadat juga, hukum-hukum dari mazhab lain diterima pakai oleh kalangan tradisionalis walaupun agak terhad, seperti dalam kes tidak batal wudhuk apabila bersentuhan lelaki dan wanita (khusus ketika tawaf), keharusan sembahyang Jumaat di tempat yang tiada pemastautin, menerima kaedah imkān alru'yah dalam menentukan awal bulan Islam, boleh membayar zakat fitrah dengan wang dan kewajipan membayar zakat gaji dan pendapatan. ${ }^{16}$ Kajian yang dilakukan oleh Anisah Abdul Ghani (et. al) ${ }^{17}$ tentang penerimaan masyarakat terhadap amalan pelbagai mazhab juga menunjukkan bahawa amalan sebegini diterima baik oleh sebahagian masyarakat Islam Malaysia walaupun tidak secara meluas.

Dalam aspek perundangan Islam pula, didapati bahawa kebanyakan enakmen atau akta ada memuatkan peruntukanperuntukan yang diambil dari pandangan-pandangan dalam mazhab-mazhab lain, sama ada dalam undang-undang kekeluargaan $^{18}$, jenayah ${ }^{19}$, acara mal, keterangan ${ }^{20}$ atau pentadbiran

15 Abdul Halim el-Muhammady (2001), Adab Berijtihad dan Berikhtilaf Mengikut Syariat. Kajang: IPI, hh. 18-19.

16 Saadan Man (2004), op.cit., hh. 301-302.

17 Lihat: Anisah Abd. Ghani (et.al) (2007), "Penerimaan Masyarakat Islam di Malaysia Terhadap Amalan Percampuran Mazhab Dalam Isu-isu Ibadat dan Kekeluargaan”, (Kertas Kerja Seminar Hukum Islam Semasa V, anjuran Jabatan Fiqh dan Usul, Akademi Pengajian Islam, Universiti Malaya, pada 22-23 Ogos 2007).

18 Lihat: ibid.; Raihanah Azahari (2007), "Kedudukan Mazhab Syafi‘i Dalam Undang-undang Keluarga Islam di Malaysia", (Kertas Kerja Seminar Hukum Islam Semasa V, anjuran Jabatan Fiqh dan Usul, Akademi Pengajian Islam, Universiti Malaya, pada 22-23 Ogos 2007).

19 Paizah Ismail (2007), "Kedudukan Mazhab Syafi'i Dalam Undangundang Jenayah Islam di Malaysia", (Kertas Kerja Seminar Hukum Islam Semasa V, anjuran Jabatan Fiqh dan Usul, Akademi Pengajian Islam, Universiti Malaya, pada 22-23 Ogos 2007).

20 Ruzman Mohd Nor (2007), “Kesaksian Dalam Konteks Undangundang Keterangan Mahkamah Syariah di Malaysia: Analisis Dari Perspektif Mazhab Syafi ‘i”, (Kertas Kerja Seminar Hukum Islam Semasa V, anjuran Jabatan Fiqh dan Usul, Akademi Pengajian Islam, Universiti Malaya, pada 22-23 Ogos 2007). 
agama Islam di negeri-negeri. Dalam perundangan fatwa di negeri-negeri pula terdapat peruntukan undang-undang yang jelas bahawa seseorang mufti atau jawatankuasa fatwa boleh mengikut qawl yang muktamad dari mazhab Hanafi, Maliki atau Hanbali sekiranya mengikut qawl yang muktamad dari mazhab Syafi'i boleh membawa kepada keadaan yang berlawanan dengan kepentingan awam. ${ }^{21}$

Di negeri Perlis, keterbukaan dalam menerima pandangan dari pelbagai mazhab yang ada boleh dilihat dengan jelas. Dalam siaran fatwanya mengenai definisi Ahl al-Sunnah wa al-Jama'ah, Majlis Agama Islam dan Adat Istiadat Melayu Perlis (MAIPs) menyatakan bahawa Majlis tidak terikat dengan mazhab-mazhab tertentu dan menerima pandangan dari mazhab-mazhab yang muktabar dalam lingkungan Ahl al-Sunnah wa al-Jama'ah. ${ }^{22}$ Ini tidaklah menghairankan memandangkan negeri Perlis adalah satusatunya negeri di Malaysia yang dikuasai oleh aliran reformisme. Namun, dengan penyelarasan perundangan Islam antara negeri ini, jelas kelihatan bahawa pengaruh mazhab Syafi'i masih lagi dominan dalam aspek ini. Walaupun kerajaan negeri berkuasa untuk tidak terikat dengan mazhab Syafi'i dalam undang-undang, jelasnya dalam hal ini mereka tidak menggunakan kuasa tersebut. Dalam hal ini, prinsip pemikiran islah atau Sunnah di negeri hanya terbatas diaplikasikan dalam proses mengeluarkan fatwa sahaja. ${ }^{23}$

21 Lihat sebagai contoh, Seksyen 36(2) Enakmen Pentadbiran Perundangan Islam Negeri Selangor 1989; seksyen 39(2) Akta 505 Pentadbiran Keluarga Islam Wilayah Persekutuan 1993.

22 Lihat Siaran Keputusan Mesyuarat Jawatankuasa Syar'iyyah Negeri Perlis, pada 18 April 1988; Noor Naemah Abd Rahman (2005), "Impak Aliran Ahl al-Sunnah wa al-Jamaah di Perlis Terhadap Perkembangan Hukum Islam Semasa: Analisis Terhadap Fatwa-fatwa Tahun 1990-2000", (Kertas Kerja Seminar Hukum Islam Semasa IV, telah dibentangkan pada 28-29 September 2005, Universiti Malaya, Kuala Lumpur, hh. 1-10; Saadan Man (2007), "Kedudukan Mazhab Syafi“i Dalam Perkembangan Ahlus Sunnah di Negeri Perlis”, (Kertas Kerja Seminar Hukum Islam V, Universiti Malaya, Kuala Lumpur).

23 Lihat Mohd Akram Dahaman@Dahlan (2005) "Metode Fatwa Jawatankuasa Syariah Negeri Perlis: Kajian Berasaskan Fatwafatwa Tahun 1990-2000", Disertasi Sarjana Jabatan Fiqh \& Usul Universiti Malaya, hh. 98-119. 
Keterbukaan pemikiran hukum sebegini seterusnya dapat dilihat dalam sistem pendidikan atau pengajian Islam di peringkat pengajian tinggi khususnya dalam kurikulum pengajian syariah. Kursus-kursus fiqh yang diajar di peringkat pengajian tinggi khususnya di universiti-universiti rata-rata bersifat eklektik, iaitu mengambilkira pandangan pelbagai mazhab. Malah, dalam sesetengah institusi pengajian agama tradisional atau pondok, pandangan-pandangan mazhab lain turut dipelajari.

Gambaran-gambaran yang dinyatakan di atas menjelaskan bahawa pemikiran hukum yang dahulunya berpaksikan kepada satu sumber sahaja iaitu mazhab Syafi'i, kini telah mengalami perubahan di mana hukum-hukum fiqh diambil dari pelbagai sumber bagi menyesuaikan dengan kepentingan umum masyarakat. Bagaimanapun, ini tidak bermakna bahawa mazhab Syafi'i tidak lagi dominan dalam masyarakat Melayu. Mazhab Syafi'i dalam kebanyakan perkara sentiasa diutamakan walaupun terdapat keterbukaan menerima pandangan mazhab lain. Ini adalah satu bentuk keterbukaan atau kebebasan terkawal yang dilakukan demi menjaga kemaslahatan masyarakat Islam di Malaysia. Hal ini dapat dilihat dengan lebih jelas, sebagai contoh, melalui apa yang dinyatakan dalam dasar pemakaian mazhab Syafi'i dalam berfatwa, sepertimana yang ditetapkan oleh Jawatankuasa Fatwa Wilayah Persekutuan: ${ }^{24}$

1. Semua fatwa yang diputuskan mestilah berdasarkan kepada qawl yang muktabar dalam mazhab Syafi'i. Jika hendak beramal dengan qawl dari mazhab lain perlu mendapat restu Yang Di Pertuan Agong.

2. Umat Islam tidak dipaksa beramal dengan mazhab Syafi' $i$ bahkan boleh beramal dengan mana-mana mazhab yang disukai dengan syarat tidak boleh menyalahkan orangorang yang beramal dengan mazhab Syafi'i.

24 Fatwa Wilayah Persekutuan (1975-1986) Minit no. 55, seperti yang dipetik dalam Ahmad Hidayat Buang (2000), "Analisis Fatwa-fatwa Semasa di Malaysia", kertas kerja Seminar Kakitangan Jabatan Syariah dan Undang-undang, telah dibentangkan pada 9 September 2000, h. 3. 
3. Mazhab-mazhab lain tidak boleh diajar atau disyarah secara terbuka di khalayak ramai, namun boleh diajar di majlismajlis pelajaran.

4. Menjadi satu kesalahan jika mengajar selain daripada mazhab Syafi'i secara terbuka.

5. Jika fatwa telah dikeluarkan berasaskan kepada mazhab Syafi'i tiada siapa pun boleh membantahnya dengan menggunakan hujah dari mazhab lain.

Dasar ini jelas sekali mempertahankan pemikiran hukum berasaskan mazhab Syafi“i seperti yang sedia ada di samping membuka sedikit ruang kepada mazhab-mazhab lain diamalkan.

\section{PANDANGAN PIHAK AUTORITI AGAMA}

Dalam kajian yang dijalankan oleh penulis khusus berhubung dengan persoalan ini, ${ }^{25}$ umumnya pihak berkuasa agama, kecuali di Perlis, tidak menerima pakai pandangan selain mazhab Syafi'i dalam permasalahan ibadah mahdah. Namun, jika ada yang ingin mengambil pandangan mazhab lain, beliau hendaklah bersifat teliti dan berhati-hati walaupun ianya tidak salah. Sebaiknya ia dilakukan setelah benar-benar mendapati beramal dengan pandangan mazhab Syafi'i membawa kesukaran, sedang mazhab lain lebih praktikal dan bersesuaian dengan situasi yang dihadapi. Ini bersesuaian dengan pandangan Imam al-Nawawi ketika ditanya pendapat berkenaan beramal dengan pandangan mazhab selain Syafi'i sebagai rukhșah disebabkan darurah dan seumpamanya, beliau menyatakan boleh beramal dengannya selagi tidak bermaksud mengambil kesenangan. ${ }^{26}$

25 Kajian di bawah peruntukan UMR FS154/2008B berjudul "Kesesuaian Pemikiran Dan Amalan Mazhab Selain Syafi'i Dalam Masyarakat Islam Di Malaysia,” 2008-2009.

26 Al-Zarkashī (t.t.), al-Baḥr al-Muhīt fì Ușūl al-Fiqh, jil. 6, hh. 325326; Lihat: Noor Naemah Abd. Rahman, Abdul Karim Ali \& Ridzwan Ahmad (2004), "Keterikatan Fatwa Kepada Mazhab Syafi'i: Analisis Terhadap Fatwa-fatwa Jemaah Ulama Majlis Agama Islam Dan Adat Istiadat Melayu Kelantan", dalam Prosiding Seminar Kebangsaan Usul Fiqh SUFI 2004. Kajang: Kolej Universiti Islam Malaysia, h. 181. 
Manakala permasalahan selain dari ibadat mahdah khususnya muamalat dan adat, ia bersifat lebih terbuka. Justeru, pemakaian mana-mana fatwa dari mazhab lain tidak mengikat seseorang mufti yang bermazhab Syafi'i. Malah dalam permasalahan semasa dan setempat, tindakan seseorang mufti merujuk dan menganalisis semua pandangan mazhab silam yang ada lebih utama dan wajar dilakukan dari hanya terikat dengan mazhab yang satu. Walaupun semua mazhab silam itu merupakan jalan yang membawa kebenaran Ilahi, namun sebagaimana dinyatakan oleh al-Syāțibī pentarjihan di antara pandangan yang ada itu perlu dilakukan demi menjauhkan diri dari mengikut hawa nafsu, di samping menjamin hukum yang dikeluarkan lebih mencapai matlamat syarak. ${ }^{27}$

Menurut pandangan tokoh-tokoh ulama tempatan kesatuan dan perpaduan ummah merupakan faktor yang paling penting untuk dinilai semasa berhadapan dengan permasalahan khiläfiyyah. Setiap isu yang berbangkit dan diketengahkan, ia perlulah dilihat dari sudut kemaslahatan, kesejahteraan dan keharmonian masyarakat khususnya. Ini bertujuan mengelak dari sebarang kekeliruan dan perdebatan hingga boleh menyebabkan berlakunya perpecahan dan perbalahan di kalangan masyarakat. Oleh itu setiap permasalahan yang boleh menimbulkan kontroversi, hendaklah dilakukan dalam perbincangan ilmiah secara tertutup di antara para sarjana hukum seperti mufti, tokoh agamawan, ahli-ahli akademik dan cendekiawan agama. Perbincangan tersebut perlulah dijalankan secara harmoni dan mengikut adab-adab ikhtiläf yang disarankan oleh Islam. Walau apa pun keputusannya, perlulah diberikan penjelasan untuk setiap hukum yang dikeluarkan bagi mengelakkan sebarang kekeliruan dan salah faham, di samping dapat mendedahkan masyarakat terhadap percambahan dan perkembangan ilmu.

Justeru, sikap keterbukaan minda terhadap percambahan ilmu dan saling hormat menghormati terhadap pandangan orang lain amat penting apabila berada dalam situasi seperti ini. Mereka perlulah bertindak mengikut realiti adat sesuatu tempat. Dengan itu, masyarakat tidak akan dapat menghukum sesama mereka,

27 Lihat al-Syātịī̄, Abū Isḥāq Ibrāhīm bin Mūsā (1997), al-Muwāfaqāt fì Ușūl al-Syarī ah, al-Syaikh Abd Allāh Darrāz (edit.), cet. 3, jil. 4. Beirut: Dār al-Ma'rifah, h. 640; Lihat Noor Naemah (et.al), op.cit. 
kerana ia boleh menyesuaikan diri dengan suasana. Namun, didikan dan ajaran terhadap asas kefahaman Islam yang sebenar dan menyeluruh perlu dititik beratkan kerana Islam ini tidak boleh diambil sebahagian sahaja tapi perlu secara menyeluruh. Jika mereka memahami kandungan al-Quran dan al-Sunnah dengan betul dan jelas, sepatutnya permasalahan sebegini tidak akan berbangkit.

Walau bagaimanapun, jika benar didapati apa yang dilakukan itu adalah satu kesilapan atau kesalahan, hendaklah ditegur dengan penuh kebijaksanaan dan secara lunak. Kebijaksaan dalam melaksanakan teguran ini amat penting bagi menghindarkan dari sebarang perbalahan, di samping perlu menjaga matlamat dan kaedahnya supaya keharmonian masyarakat itu terpelihara.

Menyentuh tentang dakwaan bahawa ajaran dan amalan mazhab selain Syafi'i ini tidak sesuai bagi masyarakat Islam yang membangun, ia sebenarnya tidaklah benar secara mutlak dan tidak begitu konsisten, kerana lazimnya keterikatan terhadap mazhab Syafi'i hanya melibatkan aspek tertentu sahaja khususnya berhubung ibadat. Sedangkan dalam aspek muamalat, ajaran mazhab lain diterima pakai dengan agak meluas. Hakikatnya dakwaan berkenaan lebih bertujuan untuk menjaga kemaslahatan umat. Oleh itu, menurut pandangan kebanyakan ulama yang ditemui, keterikatan kepada mazhab Syafi'i adalah lebih sesuai untuk realiti sekarang ini, tetapi ia perlu diasaskan dengan ilmu, bukan disebabkan ikut-ikutan ataupun taasub. Proses keilmuan ini hendaklah sentiasa berjalan kerana jika kurang kesedaran terhadap keilmuan ini, maka ramailah yang akan mengambil kesempatankesempatan tertentu dengan mengambil yang mudah sahaja. Pokoknya asas yang perlu dipegang ialah kefahaman, kesedaran Islam dan keilmuan, serta elakkan dari mengikut dorongan hawa nafsu. Selain itu perlu juga berbalik kepada satu paksi asas iaitu keharmonian hati dan perasaan dengan berpandukan kepada asas iman dan akidah yang jelas. 


\section{KHILAF FIQHIYYAH DAN KESATUAN UMMAH}

Tidak disangkal lagi bahawa kesatuan umat Islam yang utuh merupakan asas utama kepada keharmonian dan kekuatan umat Islam sejak zaman berzaman. Tidak dinafikan juga bahawa perpecahan dan kacau bilau dalam masyarakat Islam adalah menjadi sebab utama kepada kelemahan dan kemunduran umat Islam. Di antara punca-punca utama yang mengundang perpecahan dan ketidaksepakatan umat Islam masa dulu dan kini ialah salah faham terhadap konsep mazhab fiqh serta kejahilan sebab-sebab yang mengundang kepada perselisihan pendapat ulama dalam isu-isu fiqh. Kewujudan mazhab-mazhab fiqh dan kepelbagaian pandangan ulama dalam ikhtiläf fiqhi tidak pernah mengundang kepada pecah belah dan kelemahan umat Islam, bahkan mengundang kepada kerahmatan dan kemajuan umat serta menunjukkan kesyumulan Islam itu sendiri. Ikhtiläf fiqhi merupakan satu fenomena tabie dan fitrah yang berpunca daripada sifat insan dan nas syarak itu sendiri yang mengundang pelbagai tafsiran dan perspektif yang berbeza. Namun, salah anggap dan tidak faham tentang konsep ikhtiläf fiqhi boleh membawa kepada perpecahan dan kacau bilau dalam masyarakat Islam jika ia tidak difahami dan diuruskan dengan baik. Dengan mendakwa terdapatnya amalan-amalan tertentu dalam urusan ibadat masyarakat Islam sebagai terkeluar dari ajaran Islam seperti yang diajar oleh Rasulullah SAW serta dianggap bid'ah yang sesat mengundang pelbagai polemik dan keresahan umat. Salah faham ini perlu diteliti dan diperbetul demi memastikan kekuatan dan kesatuan umat Islam semasa dipelihara. ${ }^{28}$

28 Syed Salim Syed Shamsuddin (2005), "Kefahaman Terhadap Konsep ikhtilāf Fiqhi Dalam Menangani Isu Menuduh Bid‘ah Dalam Permasalahan Fiqh: Satu Tinjauan Ringkas", (Kertas Kerja Seminar Hukum Islam Semasa, telah dibentangkan pada 28-29 September 2005, anjuran Jabatan Fiqh dan Usul, Akademi Pengajian Islam, Universiti Malaya, Kuala Lumpur), h. 1; Badlihisham Mohd Nasir \& Othman Talib (2003), "Fiqh al-Ikhtilaf Menurut Dr. Yusof al-Qaradawi: Suatu Tinjauan Dari Perspektif Gerakan Dakwah", dalam Prosiding Seminar Kebangsaan Fiqh Semasa 2003, telah dibentangkan pada 2425 September 2003, anjuran Jabatan Syariah, Fakulti Pengajian Islam, Universiti Kebangsaan Malaysia, cet. 1, h. 270. 
Memandangkan fenomena ikhtilāf yang berlaku di kalangan umat Islam kini selalunya memberikan kesan yang negatif, terutamanya dari aspek kesatuan ummah, maka keperluan untuk menguruskannya secara bijaksana amatlah mendesak. Ikhtilāf yang pada asalnya dibenarkan oleh agama seringkali memberikan implikasi buruk apabila ia tidak difahami dan ditangani dengan betul, dan ini akhirnya menjadi punca kepada fenomena tafarruq atau perpecahan sebagaimana yang sering dilihat di pelusuk dunia Islam kini. Sebenarnya, ia tidaklah menggambarkan kecelaruan pemikiran Islam, tetapi sebaliknya menunjukkan kelenturan syariah Islam yang mempunyai pelbagai alternatif dalam menyelesaikan masalah, keterbukaan para fuqaha dalam menilai suasana sekitar dari persepsi yang berbeza-beza dan sebagainya. ${ }^{29}$ Dalam era yang disebut sebagai kebangkitan Islam kini, umat Islam sepatutnya sepakat dan bersatu menggembelengkan tenaga mereka untuk mengembalikan zaman keunggulan Islam. Namun hingga kini mereka masih tidak dapat mencari noktah persefahaman, sebaliknya terus bertengkar, berpuak-puak dan berpecah atas sebab-sebab yang kebanyakannya bukan merupakan dasar dan prinsip agama. Justeru, satu formula penting perlu digarap untuk mencari jalan penyelesaian supaya perkara-perkara yang menjadi perselisihan di kalangan umat Islam dapat ditelusuri dan diuruskan dengan tidak menjejaskan kesatuan ummah.

Akan tetapi realiti yang berlaku dalam masyarakat kita, perbezaan pendapat di kalangan para ulama dipandang serong. Orang ramai terbiasa diikat dengan pandangan tunggal yang diwarisi sejak lama. Berasaskan kepada kecenderungan yang tidak menguntungkan ini, ramai orang begitu sukar menerima pandangan hukum yang berbeza dari yang biasa didengari. Malah, ramai yang belum boleh menerima perbezaan pendapat antara para ulama sebagai sesuatu yang sihat. Untuk itu, masyarakat perlu disedarkan bahawa perubahan dan perbezaan pendapat di kalangan para fuqaha adalah perkara biasa yang perlu diterima dengan secara terbuka dan positif. Mereka perlu diyakinkan bahawa hukum sama seperti nilai hidup lain yang dinamis dalam

29 Lihat: Muḥammad Abū Zahrah, op.cit, jil. 2, hh. 62-78; Ṭahā Jābir al-'Alwānī (1992), Adāb al-Ikhtilāf F̄̄ al-Islām. Verginia: IIT. 
masyarakat. Ia memerlukan ruang yang cukup untuk berkembang. Tanpa ruang seperti itu, ia akan terbantut dan akan mati. ${ }^{30}$

Mengurus ikhtilāf sebenarnya tidaklah begitu sukar. Ia hanya memerlukan sedikit adunan antara kefahaman, keikhlasan, toleransi, sikap dan adab yang betul. Kita telah melihat banyak contoh yang telah ditunjukkan oleh generasi-generasi awal Islam dalam menangani ikhtilāf. ${ }^{31}$ Contoh-contoh ini haruslah dijadikan pedoman dalam kita mengatur susun kaedah dan formula bagi mengurus ikhtilāf dengan baik. Jika ditelusuri penulisan para ulamak tentang pengurusan ikhtilāf ini, kita menemui pelbagai prinsip dan formula yang digariskan mereka bersumberkan dari nas-nas al-Quran dan Sunnah, serta dipenuhi dengan kisah, pedoman dan teladan para salaf al-șälih tentang bagaimana sepatutnya $i k h t i l a \bar{f}$ ditangani. ${ }^{32}$ Antaranya adalah seperti berikut;

i) Perbezaan yang berlaku dalam masalah furu ' hendaklah diterima sebagai suatu kemestian dan rahmat. Hakikat kemestian ini dapat dilihat dari beberapa faktor seperti fitrah agama Islam yang mengandungi hukum-hakam yang qat " $\bar{\imath}$ dan zannī, muhkamāt dan mutasyabihat dan seumpamanya yang mengundang kepada pelbagai pentafsiran. Tabiat bahasa juga memainkan peranan penting justeru perbezaan fahaman terhadap lafaz-lafaz ayat di dalam nas. Ini ditambah lagi dengan sebab tabie manusia yang mempunyai keperibadian dan daya intelektual yang berbeza, di samping tabiat semulajadi alam dan kehidupan yang penuh dengan bermacam bentuk kepelbagaian.

30 Mahmood Zuhdi Ab. Majid (t.t), Hukum Islam Semasa, koleksi manuskrip dan belum diterbitkan.

31 Lihat Muhammad Abū Zahrah, op.cit, hh. 85-86; Zulkifli Mohamad al-Bakri (2005), Menyelusuri Ikhtilaf Mazhab: Antara Keterikatan \& Keterbukaan, Perpaduan \& Perpecahan, cet. 1. Kajang: Darul Fuqaha Enterprise, hh. 65-77.

32 Lihat, sebagai contoh, Yūsuf al-Qaraḍāwī (1995), al-Ṣahwat alIslāmiyyah bayna al-Ikhtiläfal-Masyrū' wa al-Ikhtiläfal-Madhmūm. Beirut: Mu'assasah al-Risālah; 'Abd Allāh Sya'bān (1997), Dawābit al-Ikhtilāf fì Mìzān al-Sunnah. Kaherah: Dār al-Hadīth; Ṭahā Jābir al-“Alwānī (1987), Adāb al-Ikhtilāe fì al-Islām. Herndon: IIIT; Muḥammad Abū al-Fatḥ al-Bayānūnī (1975), Dirāsāt fì al-Ikhtilāf al-Fiqhiyyah. Kaherah: Dār al-Salām. 
Perbezaan dalam masalah cabang fiqh ini perlu dianggap membawa rahmah, bersesuaian dengan hadis "ikhtiläf umatku adalah rahmat" 33 adalah kerana ia merupakan faktor pencetus kepada kebangkitan ijtihad dalam mengistinbat hukum Islam dalam perkara-perkara yang baru timbul. Perselisihan seperti ini dianggap sebagai tharwah yang memperkayakan lagi perbendaharaan undang-undang Islam. Ia direkodkan secara praktikal dalam konteks perbezaan imam-imam mazhab seperti Syafi‘i, Hanafi, Hanbali dan Maliki. ${ }^{34}$

ii) Saling bertoleransi dalam masalah yang diperselisihkan. Toleransi yang dimaksudkan di sini ialah tidak fanatik kepada suatu pendapat yang bertentangan dengan pendapat lain dalam masalah khilafiyyah atau satu mazhab dan seorang imam yang bertentangan dengan mazhab dan imam lain. Pelaksanaan toleransi hendaklah berdasarkan kepada beberapa prinsip iaitu; mesti menghormati pendapat orang lain, bersedia menerima kemungkinan beragamnya kebenaran dan terjadinya perbezaan dalam menilai realiti. Sekiranya dasar-dasar berkenaan dapat dipatuhi, maka masalah yang dibincangkan akan dapat berlangsung tanpa perselisihan yang boleh menimbulkan permusuhan yang berpanjangan.

iii) Meninggalkan fanatisme terhadap individu, mazhab dan golongan tertentu. Fanatisme terhadap individu atau diri sendiri sebenarnya hanya dipengaruhi oleh nafsu dan kedegilan walaupun kadangkala hujah yang dikemukakan adalah terlalu lemah. Mereka mengamalkan suatu pemikiran jumud dan beku yang langsung tidak bermanfaat bagi percambahan akal fikiran. Sikap sebahagian para pengikut yang hampir memaksumkan mazhab telah melahirkan sikap fanatisme mazhab yang sukar dileraikan. Di antara sikap golongan ini ialah mereka menganggap taklid kepada sesuatu mazhab atau para imam yang empat adalah wajib. Mereka juga

33 Riwayat al-Suyūṭ̄ dalam al-Jāmi al-Ṣaghīr sebagaimana yang dipetik dalam Yūsuf al-Qaraḍāwī (1995), op.cit., h.48; Al-Qaraḍāwī menyebut bahawa walaupun ramai ulama hadis yang mempertikaikan kesahihan hadis ini, tetapi makna hadis ini disokong oleh nas-nas lain yang menunjukkan bahawa ikhtiläf adalah satu rahmat dalam ertikata kelonggaran bagi umat islam memilih pandangan-pandangan ulamak yang ada. Lihat kupasan beliau dalam karyanya ini di hh. 47-53.

34 Al-Qaraḍāwī (1995), op.cit., hh. 46-48. 
tidak membenarkan pengikut mazhab tertentu keluar daripadanya meskipun dalam masalah yang lemah dalil mazhabnya. Seharusnya para pendokong Islam hendaklah mengambil sikap seperti yang telah ditunjukkan oleh para pengasas mazhab itu sendiri yang berlapang dada menerima pandangan mazhab lain.

\section{KESIMPULAN}

Secara umumnya, dilihat bahawa pengaruh mazhab Syafi'i dalam masyarakat Islam di Malaysia masih kukuh dan menebal. Walaupun gerakan iṣlāh sedikit sebanyak telah memecahkan dominasi pemikiran Syafi'i dalam masyarakat, namun ia tidak berjaya menguasai keseluruhan masyarakat. Sebaliknya dalam aspek-aspek tertentu, ia masih tidak dapat menembusi benteng Syāfi 'iyyah, khususnya dalam pengajaran fiqh melalui sistem dan kurikulum pendidikan agama secara formal dan juga perundangan. Justeru, walaupun ada kedengaran kata-kata bahawa keterikatan terhadap mazhab Syafi'i tidak lagi releven bagi masyarakat Islam di Malaysia dalam era globalisasi ini, realitinya ia masih lagi utuh dan diamalkan oleh masyarakat Islam Malaysia. Situasi ini dijangka berterusan kerana arus perdana masyarakat yang berpegang kepada mazhab Syafi'i adalah ampuh dan sukar digugat. Dengan kata lain, kecenderungan untuk mengamalkan Islam melalui pemikiran tidak bermazhab atau keterbukaan mazhab kurang mendapat tempat di Malaysia.

Dalam masa yang sama, majoriti ulama tempatan berpandangan bahawa aliran pembaharuan ini tidak sesuai untuk diterima pakai lantaran ia dibimbangi boleh membawa perpecahan dan ketidak harmonian dalam masyarakat Islam di Malaysia. Masyarakat Islam di Malaysia dianggap telah sebati dan selesa dengan corak amalan tradisi, dan ini harus diterima sebagai satu realiti dan faktor yang boleh menyatukan umat Islam di sini. Keselesaan ini dianggap sebagai tidak harus diganggu gugat oleh pandangan baru yang seringkali mencetuskan polemik, kegusaran dan pertikaian dalam kalangan masyarakat. 
Jurnal Fiqh, No.6 (2009) 21-40 